\title{
PERAN CIVIL SOCIETY ORGANIZATION (CSO) DALAM PERUMUSAN KEBIJAKAN PUBLIK (KAJIAN DI KABUPATEN PONOROGO)
}

\author{
Ardhana Januar Mahardhani \\ * Prodi Pendidikan Pancasila dan Kewarganegaraan, Universitas Muhammadiyah Ponorogo \\ Email: ardhana@umpo.ac.id. \\ Sulton \\ *Prodi Pendidikan Pancasila dan Kewarganegaraan, Universitas Muhammadiyah Ponorogo \\ Email: sulthon_ump@yahoo.com
}

Sunarto

*Prodi Pendidikan Pancasila dan Kewarganegaraan, Universitas Muhammadiyah Ponorogo Email: ardhana@umpo.ac.id.

\begin{abstract}
Abstrak
Setelah memasuki era reformasi, pergerakan Civil Society Organization (CSO) di Indonesia lebih berperan sebagai penyeimbang negara, peran itupun juga berlaku pada CSO yang ada di daerah, keberadaan CSO tersebut menjadi sangat penting karena menjadi alternatif penyeimbang antara kepala daerah dan DPRD, oleh karena itu keberadaan CSO dapat menjadi bagian terpenting dalam proses perumusan kebijakan agar lebih sehat, bersifat terbuka dan partisipatif. Kabupaten Ponorogo merupakan salah satu kabupaten yang sangat dinamis dalam hal keberadaan CSO yang ada ataupun kegiatan pemerintah dalam keluarnya kebijakan. Dalam proses politik yang timbul dalam penentuan kebijakan juga melibatkan peran CSO dalam rangka untuk memperkecil polemik yang ada di masyarakat Penelitian ini menggunakan desain kualitatif diskriptif karena akan menafsirkan fenomena yang terjadi di Kabupaten Ponorogo. Dari hasil penelitian, didapatkan kesimpulan yaitu Kabupaten Ponorogo akan melibatkan CSO dalam rangka menjaga prinsip keterbukaan dalam good governance, adapun peran CSO tersebut adalah: 1) Menjadi penghubung antara masyarakat dan pemerintah, 2) Mengakomodasi kepentingan masyarakat, 3) Mendorong adanya jaringan antar kelompok masyarakat, dan 4) Membangun kolaborasi antara pemerintah, masyarakat, serta pihak ketiga.
\end{abstract}

Kata Kunci: Civil Society Organization, Kebijakan Publik

\begin{abstract}
After entering the era of reform, the Civil Society Organization (CSO) movement in Indonesia has more the role of balancing the state, and that role also applies to CSOs in the regions, the existence of the CSO is very important because it becomes an alternative balancer between the regional head and the DPRD, therefore the existence of CSO can be the most important part in the policy formulation process to be more healthy, open and participatory. Ponorogo Regency is one of the very dynamic districts in terms of the existence of existing CSO or government activities in issuing policies. In the political process that arises in determining policy also involves the role of CSO in order to minimize the polemic that exists in the community. This study uses descriptive qualitative design because it will interpret phenomena that occur in Ponorogo Regency. From the results of the study, it was concluded that Ponorogo Regency will involve CSO in order to maintain the principle of openness in good governance, while the role of CSO is: 1) Become a liaison between the community and the government, 2) Accommodate community interests, 3) Encourage the existence of networks between community groups, and 4) Building collaboration between government, the community and third parties.
\end{abstract}

Keywords: Civil Society Organization, Public Policy

\section{PENDAHULUAN}

Dalam segala aspek kehidupan, pemerintah mempunyai andil besar dalam rangka menciptakan iklim yang kondusif guna memprediksi apa saja yang akan terjadi. Kovner (Mahardhani (2014: 24) menyatakan bahwa terdapat tiga hal yang harus diperankan oleh pemerintah, yang pertama adalah peran pemerintah sebagai regulator, kedua sebagai pemberi biaya, dan ketiga sebagai pelaksana kegiatan. Dalam hal sebagai regulator, pemerintah daerah dituntut untuk merumuskan berbagai kebijakan yang ditujukan oleh masyarakat atau sswasta dengan baik, seimbang, dan selalu mementingkan kepentingan masyarakat.

Banyak kelompok dalam masyarakat yang membutuhkan eksistensi dan pengakuan dalam kehidupan pemerintahan, dalam melakukan kebersamaannya kelompok masyarakat itu diwadahi dalam Civil Society Organization (CSO). 
Di tangan para pakar, CSO muncul dengan beragam konsep, sesuai dengan perspektif dan paradigma yang dikembangkan. Sebagian menyebutnya sebagai masyarakat sipil, masyarakat beradab, masyarakat berbudaya, masyarakat madani dan sebagainya, mencakup organisasi keagamaan, organisasi berbasis massa, perserikatan, etnis asosiasi profesional dan lain-lain, yang biasa berada di luar aparat negara yang formal (Malik, tanpa tahun: 3 ).

CSO pada dasarnya mempunyai peran penting dalam agenda-agenda reformasi seperti penegakan supremasi hukum, pemberantasan budaya korupsi, kolusi dan nepotisme (KKN), otonomi daerah, dan lainnya. Dalam kaitannya dengan hal ini, penting merefleksikan kembali bagaimana posisi dan peran CSO sebagai bagian dari pilar pembangunan demokrasi, meletakkan diri dan mengambil peranan dalam pencapaian ini.

Salah satu aspek penting dari peran CSO bagi pembangunan dan kebijakan adalah peran kritis yang dimainkan sebagai gerakan penyeimbang negara dalam menjalankan program pembangunan yang inklusif dan berkelanjutan. Kehadiran CSO sebagai representasi masyarakat sipil merupakan faktor penting sebagai bagian dari upaya mewujudkan pembangunan yang berkelanjutan, sebuah paradigma pembangunan untuk memenuhi kebutuhan generasi saat ini tanpa mengorbankan pemenuhan kebutuhan generasi masa depan. Oleh karenanya CSO harus memiliki ketrampilan dalam membangun metode dan pendekatan baru untuk penelitian dan perencanaan pembangunan serta memiliki kemampuan sebuah inovasi baru, selain itu CSO memiliki peranan dalam mendorong proses pembangunan yang bersifat partisipatori (Pambudi, 2006: 18)

Berdasarkan peran yang telah diuraikan di atas, masalah yang akan dikaji dalam penelitian ini adalah bagaimana peran Civil Society Organization (CSO) dalam pembuatan kebijakan publik di Kabupaten Ponorogo. Sedangkan tujuan yang hendak dicapai adalah mengetahui, mendiskripsikan, dan menganalisa peran Civil Society Organization (CSO) dalam pembuatan kebijakan publik di Kabupaten Ponorogo.

\section{METODE}

Penelitian ini menggunakan pendekatan deskriptif kualitatif. Denzin dan Lincoln dalam Moleong (2007: 5) menyatakan bahwa penelitian kualitatif adalah penelitian yang menggunakan latar ilmiah, dengan maksud menafsirkan fenomena yang terjadi dan dilakukan dengan jalan melibatkan berbagai metode yang ada.

Prosedur yang dipakai dalam pengumpulan data, yaitu observasi, wawancara, dan studi pustaka. Data yang diperoleh dari penelitian ini akan dianalisis dengan menggolongkan, mereduksi, dan menghilangkan data yang tidak sesuai kemudian dipaparkan secara deskriptif.

\section{HASIL DAN PEMBAHASAN}

\section{A. Keberadaan Civil Society Organization di Kabupaten Ponorogo}

Sebelum membentuk sebuah organisasi yang formal, masyarakat dihadapkan dengan berbagai masalah yang harus dicukupi termasuk dengan bantuan keberadaan pemerintah, masyarakat sebagai sebuah civil society menurut Hikam (Rosyada, 2003: 240) adalah wilayahwilayah kehidupan sosial yang terorganisasi dan bercirikan antara lain kesukarelaan (voluntary), keswasembadaan (self-generating), dan keterlibatan (self-supporting), kemandirian tinggi berhadapan dengan negara dan keterkaitan dengan norma-norma atau nilai-nilai hukum yang diikuti oleh warganya.

Selanjutnya Gellner (Rosyada, 2003: 119) menjelaskan bahwa civil society bukan hanya merupakan syarat penting atau prakondisi bagi demokrasi semata, tetapi tatanan nilai dalam masyarakat madani (civil society) seperti kebebasan dan kemandirian juga merupakan sesuatu yang inheren baik secara internal (dalam hubungan horizontal yaitu hubungan sesame warga negara) maupun secara eksternal (dalam hubungan vertical yaitu hubungan negara dan pemerintah dengan masyarkat atau sebaliknya).

Dalam kehidupan masyarakat, akan lebih kuat jika diantara civil society membentuk sebuah kelompok yang mengintegrasi semua masyarakat dengan kepentingan dan tujuan yang sama. Jika di Indonesia integrasi dalam sebuah organisasi tersebut dikenal dengan istilah NGO (Non Government Organization) dan Lembaga Swadaya Masyarakat (LSM), dan dari kelompok-kelompok tersebut yang kemudian dikenal sebagai Civil Society Organization (CSO)

Dengan semakin majunya demokrasi di Indonesia tentunya juga menjadikan masyarakat semakin peka terhadap masalah-masalah sosial dan selalu akan mengikuti perkembangan apa yang telah dilakukan oleh pemerintah, termasuk dalam pembuatan kebijakan publik. Masyarakat yang sama-sama mempunyai kepentingan tersebut akan berkelompok menjadi satu karena merasa mempunyai kepentingan yang sama, mereka membentuk sebuah organisasi masyarakat. Di Kabupaten Ponorogo sendiri banyak terdapat CSO dengan berbagai bidang, tetapi dalam penelitian ini hanya beberapa CSO yang akan kami lihat bagaimana pergerakan yang ada di Kabupaten Ponorogo dalam rangka perumusan kebijakan publik.

Berikut adalah CSO yang ada di Kabupaten Ponorogo:

1. Muhammadiyah, organisasi masyarakat ini juga telah berkembang di Kabupaten Ponorogo dalam berbagai bidang, yaitu keagamaan, pendidikan, kesehatan, sosial, ekonomi, dan hukum serta masing-maisng mempunyai tujuan utama adalah pemberdayaan dan pengembangan masyarakat, banyak lembaga yang telah didirikan oleh Muhammadiyah di Kabupaten 
Ponorogo diantaranya rumah sakit, klinik, sekolah, perguruan tinggi, lembaga sosial, serta pusat perdagangan.

2. Nahdlatul Ulama, organisasi ini berbasis pada agama, dalam skala nasional organisasi ini telah berkembang pesat dalam berbagai bidang, di Kabupaten Ponorogo juga demikian, organisasi ini mempunyai fokus dalam pengembangan masyarakat dan bergerak di bidang keagamaan, pendidikan, sosial, ekonomi, dan kesehatan. Banyak juga di Kabupaten Ponorogo lembaga-lembaga yang telah didirikan oleh Nahdlatul Ulama.

3. Yayasan Reyog Ponorogo, organisasi ini mempunyai fokus pada pelestarian tradisi khususnya Reyog Ponorogo yang saat ini sudah dikenal seluruh Indonesia bahkan di luar negeri. Keberadaan Yayasan Reyog Ponorogo ini adalah sebagai organisasi yang mengayomi keberadaan kelompok seni reyog yang ada di seluruh Kabupaten Ponorogo agar tetap terjaga, berkelanjutan, dan sesuai dengan pakem.

4. Yayasan Inisiatif Perubahan Akses menuju Sehat Indonesia (IPAS), organisasi ini tidak hanya berada di Kabupaten Ponorogo, melainkan ada di seluruh Indonesia, meskipun demikian keberadaan organisasi ini sangat membantu Dinas Kesehatan Kabupaten Ponorogo dalam membuat kebijakan-kebijakan terkait dengan kesehatan reproduksi, Angka Kematian Ibu (AKI), dan Angka Kematian Bayi (AKB).

\section{B. Civil Society Organization (CSO) dalam Perumusan Kebijakan Publik di Kabupaten Ponorogo}

Tentunya semakin banyak CSO yang ada di Ponorogo berdampak pada adanya proses untuk transparansi dalam perumusan kebijakan publik dalam segala aspek. Sumarto (2009: 31) menyebutkan ada empat peran utama CSO tersebut, diantaranya adalah peningkatan kesadaran (awareness raising), advokasi kebijakan (policy advocacy), pengembangan institusi (institutional building), dan pengembangan kapasitas (capacity building).

Dalam pelaksanaannya CSO yang ada di Kabupaten Ponorogo telah memainkan perannya dalam rangka perumusan kebijakan publik yang ada di Kabupaten Ponorogo, diantaranya adalah peraturan daerah yang telah disusun oleh DPRD Kabupaten Ponorogo tentu juga melibatkan pihak CSO dalam rangka mendapatkan informasi tambahan dan masukan terkait dengan bidangnya masing-masing.

Melihat hal tersebut peran CSO dalam perumusan kebijakan publik di Kabupaten Ponorogo dapat dilihat sebagai berikut:

1. Menjadi penghubung antara masyarakat dan pemerintah,

Menjadi penghubung di sini adalah adanya permasalahan yang dihadapi oleh masyarakat, CSO dituntut untuk selalu hadir di tengah-tengah masyarakat untuk menjadi advocate, hal ini dikarenakan masyarakat tidak mempunyai akses untuk masuk secara langsung dalam proses perumusan kebijakan publik. Masyarakat hanya bisa memberikan suara melalui saluran-saluran yang terbatas sehingga banyak masukan dari masyarakat yang tidak bisa tersalurkan.

2. Mengakomodasi kepentingan masyarakat,

CSO mempunyai tugas salah satunya adalah harus tanggap dalam mengatasi masalah yang ada di masyarakat, selain itu juga selalu berkomunikasi secara baik dengan masyarakat agar apa yang diinginkan oleh masyarakat dapat diakomodir dengan baik.

3. Mendorong adanya jaringan antar kelompok masyarakat,

Kelompok-kelompok yang ada di masyarakat sangat beragam dan masing-masing mempunyai kepentingan masing-masing, oleh karenanya adanya banyak kelompok masyarakat akan mempermudah dalam mengakomodir kepentingan yang ada. CSO dalam hal ini juga akan semakin mudah untuk mengelompokkan kelompok-kelompok masyarakat tersebut dengan pembentukan kebijakan yang akan disusun oleh pemerintah.

4. Membangun kolaborasi antara pemerintah, masyarakat, serta pihak ketiga.

Prinsip kolaborasi dibutuhkan sebagai bentuk dari adanya keterbukaan dan partisipasi dalam prinsip good governance. Pihak ketiga dibutuhkan untuk dapat memberikan masukan tambahan atas masalah yang belum bisa terselesaikan oleh pemerintah ataupun CSO. Tidak semua masalah bisa terjawab oleh keduanya, oleh karena itu masih dibutuhkan pihak ketiga untuk dapat menyelesaikan permasalahan yang ada di masyarakat. CSO mempunyai tugas membangun hubungan baik antara masyarakat, pemerintah, dengan pihak yang dilibatkan dalam proses perumusan kebijakan di daerah.

\section{PENUTUP \\ Simpulan}

Keberadaan CSO yang beragam dengan multi kepentingan di Kabupaten Ponorogo akan dapat membantu pemerintah dalam menyelesaikan permasalahan melalui disusunnya kebijakan publik berupa peraturan daerah. Hubungan yang baik antara pemerintah daerah, masyarakat, dan CSO juga harus dapat dijaga dengan bekerja sesuai dengan perannya masing-masing. CSO di Kabupaten Ponorogo dalam proses perumusan kebijakan publik mempunyai peran yang sangat penting, yaitu pertama menjadi penghubung antara masyarakat dan pemerintah, kedua mengakomodasi kepentingan masyarakat, ketiga mendorong adanya jaringan antar kelompok masyarakat, dan keempat membangun 
kolaborasi antara pemerintah, masyarakat, dan pihak ketiga.

\section{Saran}

Melibatkan CSO dalam proses perumusan kebijakan publik yang ada di daerah merupakan hal yang sangat penting dan sebuah keniscayaan, adanya hubungan baik yang selalu terjalin menjadikan peran CSO dalam proses perumusan kebijakan publik bisa maksimal. Selain itu pemerintah daerah juga harus selalu memberikan tempat yang baik untuk CSO karena keberadaanya menjadi penghubung antara kepentingan masyarakat dan kebijakan pemerintah, sehingga dari sini prinsip transparansi dan kolaborasi akan tetap dapat terlaksana dengan baik.

\section{DAFTAR PUSTAKA}

Mahardhani, Ardhana Januar. 2014. Strategi Pembangunan Desa. Ponorogo: Unmuh Ponorogo Press

Malik, Imam. tanpa tahun. Peran penting Civil Society Organization (CSO) dalam Penanganan Terorisme. Jakarta: C-Save Indonesia

Moleong, Lexy. J. 2007. Metodologi Penelitian Kualitatif. Bandung: PT Remaja Rosdakarya

Pambudi, A. Panggo Wahyu. 2016. Stratgei Civil Society Organization dalam Menangani Eksploitasi Seksual Komersial Anak (ESKA) di Kota Bandarlampung. Skripsi. Fakultas Ilmu Sosial dan Ilmu Politik Universitas Lampung.

Rosyada, Dede, dkk. 2003. Pendidikan Kewarganegaraan: Demokrasi, Hak Azasi Manusia, Masyarakat Madani. Jakarta: Prenada Medika.

Sumarto, Hetifah SJ. 2009. Inovasi, Partisipasi, dan Good Governance 20 Prakarsa Inovatif dan Partisipatif di Indonesia. Jakarta: Yayasan Obor Indonesia 